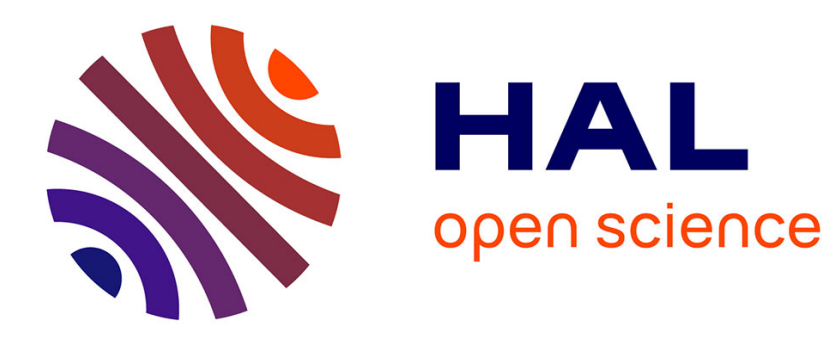

\title{
Influence of the International Labour Migration on a National Economy of Armenia \\ Koryun Atoyan
}

\section{To cite this version:}

Koryun Atoyan. Influence of the International Labour Migration on a National Economy of Armenia. International Conference on Arts, Economics and Management (ICAEM'14), Mar 2014, Dubai, United Arab Emirates. pp.67-70, 10.15242/icehm.ed0314020 . hal-03283594

\section{HAL Id: hal-03283594 \\ https://hal.science/hal-03283594}

Submitted on 12 Jul 2021

HAL is a multi-disciplinary open access archive for the deposit and dissemination of scientific research documents, whether they are published or not. The documents may come from teaching and research institutions in France or abroad, or from public or private research centers.
L'archive ouverte pluridisciplinaire HAL, est destinée au dépôt et à la diffusion de documents scientifiques de niveau recherche, publiés ou non, émanant des établissements d'enseignement et de recherche français ou étrangers, des laboratoires publics ou privés. 


\title{
Influence of the International Labour Migration on a National Economy of Armenia
}

\author{
Koryun Atoyan
}

\begin{abstract}
Migration for employment is an important global issue, which now affects most countries in the world. Two major labour market forces are in operation today that result in increased migration for work - many people of working age either cannot find employment or cannot find employment adequate to support themselves and their families in their own countries, while some other countries have a shortage of workers to fill positions in various sectors of their economies. Other factors include demographic change, socio-economic and political crises, and widening wage gaps within, as well as between, developed and developing countries. There is consequently much movement across borders for employment, with women independently migrating for work in considerably greater numbers than in the past and now comprising about half of all migrant workers.

One important feature of modern globalization involves migration. The world has seen recent growth in immigration to developed countries. The number of working-age individuals born in one country and living in another country increased from 42 million in 1990 to 59 million in 2000, or 1.7 million per year, on average. According to Massey and Taylor (2004), contemporary international migration unfolds in a context of the globalization of markets. The United States is by far the world's largest immigrant destination. The global financial crisis that took place in the third quarter of 2008 creating a strong negative impact for many countries, companies and employees that worked in many developing countries. The ILO (International Labour Organization) provided a quick reaction by looking at the consequences related to the employment and job conditions. It was estimated that by 2009,50 million jobs would be lost [1]. This is the reason why it is a fact that the ILO has paid exacting concentration to policies consequences which gave them an enough chance to study the matter in detail. The ILO passed a declaration of global jobs pact which allowed companies and the employees to make use of their complete potential of their productive resources. Therefore, all the issues related to International Labour Migration will be discussed in detail.
\end{abstract}

Keywords-Migration, labour market, international migrants, labour migration, global employment.

\section{INTRODUCTION}

$\mathrm{M}$ IGRATION for employment is an important global issue, which now affects most countries in the world. Two major labour market forces are in operation today that result in increased migration for work - many people of working age either cannot find employment or cannot find

Koryun Atoyan is with the Armenian State University of Economics, Yerevan, 0025. Armenia. (Corresponding author's phone: +37491-211917 ; e-mail: Prof_Mkhitaryan@yahoo.com). employment adequate to support themselves and their families in their own countries, while some other countries have a shortage of workers to fill positions in various sectors of their economies. Other factors include demographic change, socioeconomic and political crises, and widening wage gaps within, as well as between, developed and developing countries. There is consequently much movement across borders for employment, with women independently migrating for work in considerably greater numbers than in the past and now comprising about half of all migrant workers [1].

The international migration renders economic influence on the countries accepting a labour, and on the countries delivering it. All over the world population shift is more and more perceived as a resource on which productive use depends economic development of the country essentially.

The analysis of interactions of economic development of the country and population shift contains following components

- Migration and macroeconomic processes, mutual communication of a total internal product and migration, a wage level, inflationary processes, investment of activities, demand of the goods, volumes of raised taxes and other macroeconomic parameters, influence of remittances of migrants on the balance of payments of the country,

- Migration and a labour market, influence of migratory processes on a rate of unemployment, a supply and demand of a labour, on a competition of workplaces between local residents and migrants,

- Migration and employment of the population, structural changes in sphere of employment of the population (according to qualification, spheres of performance of works, branches of economy), influence of migration on quantity of manpower,

- Migration and macroeconomic processes, an estimation of productivity of trips, influence of migratory processes on house facilities, a standard of living.

Migration and the latent processes, influence of migration on shadow economy, volumes of illegal employment,

- Migration and social policy, the state expenses directed on acceptance of migrants and social adaptation, social security of migrants, creation of an additional infrastructure, a role of migration in business of reforming of pension system.

Simultaneously migratory currents have turned to the global phenomenon which influences all aspects of a life of the world community. Migratory currents are formed in conditions of change of a population of a planet. Thus, during with 1900- 
2000 population size has increased from 1,6 billion up to 6 billion, and according to calculations of experts of the United Nations in 2050 number will reach 9 billion.

Anyhow, by estimations of international experts, the aggregate number of the international migrants in 2006 has made 190,6 million person from which 115,4 million live in the developed countries $(60,5 \%), 75,2$ million in developing countries $(39,5 \%)$, including 10,5 million in more developed regions (5,5\%). In 1990-2012 number of migrants in the world has grown up to 56 million. Rates of growth of migrants have grown from $1,4 \%$ in $1990-2000$ up to $2.4 \%$ in 2000 2012. In the developed countries quantity of migrants during 1990-2011 has increased on 33 million, and in developing countries on 3 million. As a result, the increasing of the international migrants concentrates in the developed regions of the world (Table I).

TABLE I

TEN STATES ON NUMBER OF IMMIGRANTS IN CONDITION ON JANUARY 1, 2013*

\begin{tabular}{|c|c|c|}
\hline The country & $\begin{array}{c}\text { Number of } \\
\text { immigrants }\end{array}$ & $\begin{array}{c}\text { For immigrants in } \\
\text { an aggregate } \\
\text { number of the } \\
\text { population of \% }\end{array}$ \\
\hline USA & 38,4 & 12,9 \\
\hline Russia & 12,1 & 8,5 \\
\hline Germany & 10,1 & 12,2 \\
\hline Ukraine & 6,8 & 14,4 \\
\hline France & 6,5 & 10,7 \\
\hline Saudi Arabia & 6,4 & 26 \\
\hline Canada & 6,1 & 18,9 \\
\hline India & 5,7 & 0,5 \\
\hline Great Britain & 5,4 & 9 \\
\hline Spain & 4,8 & 11 \\
\hline
\end{tabular}

Source `http // ww2.unhabitat.org/programmes/guo/

\section{II.INTERNATIONAL LABOUR MIGRATION: ISSUES AND PROBLEMS}

As to the basic geographical regions of the world in 2010 in the Europe the greatest quantity of the international migrants (more than 64 million people has been concentrated), then in Asia and Northern America. In the European countries there are $33,6 \%$ of the international migrants, in Asia $28 \%$, Northern America 23,3\%. In Africa $9 \%$ of the international migrants, in Latin America and in the countries of Caribbean basin less than $4 \%$, Oceania less than $3 \%$ are concentrated.

In $199675 \%$ of total of migrants have been concentrated in 30 countries, and in 2012 in 28 countries. In this group on leading positions were the USA where in 1990 were concentrated $15 \%$ of migrants and in 2012 more than $30 \%$.

$75 \%$ of all international migrants during 1995-2012 were concentrated in 17 countries of the world. The quantity of migrants in the USA has grown on 15 million people, in Germany and Spain more than 4 million. At the same time, quantity of migrants was reduced in 72 countries. The greatest reduction of quantity of migrants has been registered in Iran and Pakistan which has been connected with homecoming the Afghani refugees [2].
Migrants make more than $20 \%$ of the population of 41 countries of the world from which in 31 countries it is registered less than 1 million populations. The centralized countries of migrants are members of Cooperation Council for the Arab States of the Gulf, also Hong Kong, Israel, Jordan, Singapore and Switzerland. In Australia and Saudi Arabia where the total of the population exceeds 10 million person, migrants make $1 / 5$ part of the population. In Canada their share less than $18,9 \%$, in the USA - $12,9 \%$, in the Russian Federation $-8,4 \%$.

For example, at the turn of 20-21 centuries the Russian Federation was the second host country / after USA/ and the first in the Europe nearby - with 13,3 million or $7.6 \%$ of migrants in the world. In 2010 on a constant place for residence has arrived to the Russian Federation about 182,4 thousand people, has left the country 54,1 thousand. The quantity of arrived to Russia has exceeded to quantity of left on 128,3 thousand people. This parameter has exceeded parameters of the last 5 years (in 2009 - 107,4 thousand person, 2008 - 39,4 thousand person, $2007-35,1$ thousand, 2006r.-72,3 thousand.), however considerably below, than parameters of the middle of 1990.

In comparison with 2010, in 2012 a migratory level person has made $19,4 \%$ or 20,9 thousand. It is caused by reduction of quantity leaving of the country, begun with the beginning of 1990, and also growth of number registered.

In 2010, 95 \% immigrated to the Russian Federation were from the CIS countries. The quantity emigrated of Russia in 2009 has decreased in comparison with the last years.

On the whole, in 2010 to the CIS and the Baltic's has arrived 36,0 thousand person (in 2009 - 36,8 thousand, in 2008 - 37,8 thousand, 2007 - 47,0 thousand, $2006-53,0$ thousand, 2005 - 62,6 thousand), and to other countries of the world 18,1 thousand person (accordingly -33 thousand, 42 thousand, 53,7 thousand and 58,6 thousand).

At the same time, it is necessary to consider, that today the international migration, as before, closely connected with social and economic development of the countries, both importing and exporting a labour, and has both positive, and negative consequences.

Considering influence of the international migration on a level of economic development of the states, it is possible to allocate the certain advantages which are provided with migration on the countries-exporters. First of all, in the country-exporter of a labour unemployment and charges of social security of unemployment is reduced, the citizens working abroad, sending regularly a part of their income to the hometown for raising a standard of life of the population and improving the balance of payments. Besides the labour which is being in abroad, getting as a rule, higher qualification, raising an educational level and returning back home with some monetary or non-material capital. 
TABLE II

POSSIBLE SOCIAL AND ECONOMIC CONSEQUENCES OF THE INTERNATIONAL MIGRATION OF LABOUR

\begin{tabular}{|c|c|c|}
\hline & Positive & Negative \\
\hline \multirow{4}{*}{$\begin{array}{l}\text { The country } \\
\text { exporting a } \\
\text { labour }\end{array}$} & $\begin{array}{l}\text { Mastering by workers of } \\
\text { new qualification }\end{array}$ & Loss of the qualified labour \\
\hline & $\begin{array}{l}\text { Reduction of deficiency of } \\
\text { the balance of payments }\end{array}$ & $\begin{array}{l}\text { Strengthening of } \\
\text { dependence of a labour and } \\
\text { the goods from foreign } \\
\text { demand }\end{array}$ \\
\hline & $\begin{array}{l}\text { Easing of a pressure in a } \\
\text { home market of work }\end{array}$ & $\begin{array}{l}\text { Reorientation of capital } \\
\text { investments - from } \\
\text { mastering industrial } \\
\text { resources to consumption }\end{array}$ \\
\hline & $\begin{array}{l}\text { Simplification of } \\
\text { technological and structural } \\
\text { reconstruction of } \\
\text { manufacture }\end{array}$ & Growth of rate of inflation \\
\hline \multirow{5}{*}{$\begin{array}{l}\text { The country } \\
\text { importing a } \\
\text { labour }\end{array}$} & $\begin{array}{l}\text { Maintenance of regions with } \\
\text { a labour }\end{array}$ & $\begin{array}{l}\text { suspense of ntroductions of } \\
\text { economic technologies }\end{array}$ \\
\hline & $\begin{array}{l}\text { Employment of workers of } \\
\text { the given district in the } \\
\text { works demanding higher } \\
\text { qualification }\end{array}$ & $\begin{array}{l}\text { Deterioration of a condition } \\
\text { of a home market of work }\end{array}$ \\
\hline & $\begin{array}{l}\text { Reduction of cost of a labour } \\
\text { and the general charges in } \\
\text { conditions of attraction of } \\
\text { immigrants }\end{array}$ & $\begin{array}{l}\text { Increase of number of } \\
\text { foreign unemployment and } \\
\text { increase in charges for the } \\
\text { maintenance of their } \\
\text { families }\end{array}$ \\
\hline & $\begin{array}{l}\text { Restraint of inflation owing } \\
\text { to savings of immigrants }\end{array}$ & \\
\hline & $\begin{array}{l}\text { Improvement of quality of a } \\
\text { labour on means of a choice } \\
\text { of younger workers }\end{array}$ & \\
\hline
\end{tabular}

Besides labour migration has the negative parties influencing to the economy of the country-exporter. First of all, the labour for which reproduction a national resource have been spent, leaving abroad, creates result of a total internal product not in own, and in a host country. Secondly, remittances of migrants usually are unpredictable and having not constant character. Thirdly, to abroad are moving usually the best experts -scientists, art workers, the sportsmen with high qualification, that unequivocally weakens both national economy, and scientific potential. And fourthly, departing abroad on a long time or for a constant place the residences, the big capital owners deprives a private sector and the state budget of financial assets, reduces economic, social at cultural base of financing.

In the developed countries the State expenditure of the social help make a significant part of budgetary charges, hence, presence of social guarantees for the poor countries are stronger stimulus, than a difference in wage levels[3].

The foreign citizens working in those or other countries, have an opportunity to use social services -the state public health services, formation, social security, etc.

It is natural, that the basic payments in the budget are carried out by local tax bearers for that simple reason, that as a rule, them it is more, than the foreigners working in the country.

Migrants-employers are paying taxes -first of all the profit tax, and also the tax to property, the tax for money transfers, etc. Besides, the salary of migrants includes all those taxes that paying organization for social insurance, assignments in a pension fund, the road tax, the tax to property, etc. Thus, that price which is created by the migrant "works" in favor of a society of a host country.

Illegal foreign workers do not pay direct taxes; however on means of the payments which are carried out by the enterprise in favour of the state, they also promote growth of public finances of a host country. If employers will not use illegal work of migrants, they will be unable to pay official state taxes. At the same time, illegal migrants in consequence of the illegal status have no rights to use the state programs of social support that called by P.Lindertom " pure tax bearers "[4].

Concerning workers-migrants, it is possible to make a conclusion, that the taxes paid by them during their stay exceed the price of the public blessings which they use during their stay in the country. It is the most actual in case of with formed and having high qualification of migrants. Formation is the most necessary and valuable service which is given by the state to citizens and having received formation and qualification of the expert in own country /for the account of tax bearers of the country/, migrants use the knowledge in a host country where they works and pay taxes. If they receiving rather high salary, the taxes paid by them are high enough and exceed the price of those public blessings which they use.

For example, in Russia, for foreign employer is obliged to calculate surtax for the first half a year, however not at a rate of $13 \%$ as Russians, but $30 \%$. Subsequently, if the employee remains for longer term, unduly paid taxes should be returned to it. Except for high taxing, from non-residents the uniform social tax is raised, thus deduction from the salary of the migrant reaches $56 \%$.

It is necessary to note, that a foreign currency received due to remittances by the countries - exporters are major "indemnification" for time or constant losses of the highly skilled staff.

If the migrant goes without family or on the Native land living his parents and other relatives, the part of the income was transferring through banking system or through other intermediary financial institutions. For migrants is typical the high norm of savings and cost savings. International researchers marked, that in parallel growth of staying duration of migrants in the country, the sizes of money transfers were reduced. The migrants, who were staying in abroad together with families, usually transferring to the relatives less money resources, than those persons, who live without family.

In structure of redistribution of monetary funds existed total differences between the countries. Thus, migrants from Asian countries have modest needs and less expenses of money resources, hence the most part of the earned means send home. 
What about migrants from European countries, we should constant, that their operational expenditure exceed the sums which transferring to hometowns.

In a context of the above-stated, it is obvious, that the international migration is the disputable and ambiguous phenomenon and demands concrete measures for the decision which should be realized through-legal regulation of migratory processes, considering global interests of the international community, objective opportunities of the separate countries and specificity of development of the population in modern conditions.

In conditions of globalization the major factor socially economic development of the majority of the countries becomes the international population shift which promotes formation of a flexible labour market, adaptations of achievements scientific and technical progress of new developing countries, to more rational use of a manpower, interaction and mutual enrichment of world civilizations.

Formation of the international labour market testifies that the international integration processes proceed not only in economic and technological spheres, and also include more complex spheres of social and labour attitudes and have global character.

\section{CONCLUSION}

International labour migration is defined as the movement of people from one country to another for the purpose of employment. Today, an estimated 105 million persons are working in a country other than their country of birth. Labour mobility has become a key feature of globalization and the global economy with migrant workers earning US\$ 440 billion in 2011, and the World Bank estimating that more than $\$ 350$ billion of that total was transferred to developing countries in the form of remittances. However, despite the efforts made to ensure the protection of migrant workers, many remain vulnerable and assume significant risks during the migration process.

When properly managed, labour migration has far-reaching potential for the migrants, their communities, the countries of origin and destination, and for employers. While job creation in the home country is the preferred option, demographic, social and economic factors are increasingly the drivers of migration. As a result, a growing number of both sending and receiving countries view international labour migration as an integral part of their national development and employment strategies. On one hand, countries of origin benefit from labour migration because it relieves unemployment pressures and contributes to development through remittances, knowledge transfer, and the creation of business and trade networks. On the other hand, for destination countries facing labour shortages, orderly and well-managed labour migration can lighten labour scarcity and facilitate mobility.

The number of international migrants has more than doubled since 1965. According to the United Nations Population Division, 191 million people - that is about $3 \%$ of the world population - lived and worked outside their country of birth in 2005, as opposed to 75 million (2.3\%) in 1965 [5]. Given the global demographic transition - shrinking and aging populations in the developed world juxtaposed with quickly expanding populations in the developing world - and given the economic gaps between the developed and the developing world, international migration is bound to increase in the future.

\section{REFERENCES}

[1] ILO Multilateral Framework on Labour Migration Non-binding principles and guidelines for a rights-based approach to labour migration. INTERNATIONAL LABOUR OFFICE GENEVA, 2006

[2] David Bartram. International Labor Migration: Foreign Workers and Public Policy. 2005

[3] The Labour Markets of Emerging Economies: Has growth translated into more and better jobs?. Edited by Sandrine Cazes and Sher Verick. 31 October, 2013

[4] Global Employment Trends 2013: Recovering from a second jobs dip. Report. 22 January, 2013

[5] Marc Lavoie and Engelbert Stockhammer. Wage-led Growth: An equitable strategy for economic recovery. 15 November 2013. 